\title{
MedienPädagogik
}

www. medienpaed.com

Zeitschrift für

Theorie und Praxis

der Medienbildung

ISSN 1424-3636

Themenheft Nr. 24: Educational Media Ecologies

\section{Foundations of Socio-Cultural Ecology Consequences for Media Education and Mobile Learning in Schools}

Klaus Rummler

\begin{abstract}
This conceptual paper offers insights to the foundations of Socio-Cultural Ecology and relates this concept to traditional concepts of Ecology e.g. media ecology or Bronfenbrenner's ecological model of child development. It will further discuss the term "ecology» as a relation between learners and their surrounding physical and structural world, e.g. an ecology of resources or the classroom as an ecological system. Thirdly more recent concepts in ecology will be considered e.g. Digital Media Ecology including media ecology (German: Medienökologie) from a German perspective. This contribution tries to describe common principles of (media) ecologies and will ask after their meaning and relation to media education and mobile learning. One of the main results is the realisation that cultural practices of school learning and cultural practices of media acquisition take place in different worlds or in different ecological spheres. The question is thus again of how to bridge these ecological spheres, and how «agency» developed outside school, can be nourished inside school. In other words: how can we bridge socio-cultural and technological structures within these cultural practices.
\end{abstract}

\section{Socio-Cultural Ecology and its backgrounds, using the example of some of the at-risk learners' usage patters of mobile technologies}

Media and technology are an important part of everyday life and the term mediatization describes this complex interrelation between changes in media and mass communication, and changes in culture and society (Hepp and Krotz 2012, 11). Face-to-face communication today is supplemented but not supplanted by technology. Media and technology are seen as cultural products that have been developed and emerged within certain cultures and are thus parts of these cultures. For young people, appropriation then means the competent integration of these cultural products into their life-worlds as such objects are available as cultural resources. In this perspective learning is just a more specific form of appropriation and very common for children and adolescents.

When focussing on new forms of appropriation and learning among young people, especially where mobile technologies are at play (Mobile Learning), it 
seems necessary to consider a triangular relation between the individuals' agency, socio-cultural and technological structures and relating cultural practices (Pachler, Bachmair, and Cook 2010).

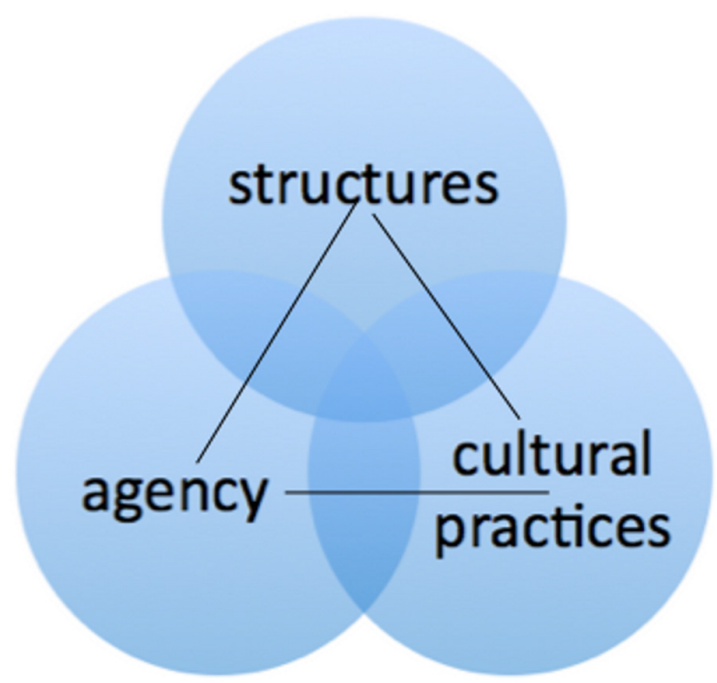

Fig. 1: Triangle of the «Mobile Complex» (Pachler, Bachmair, and Cook 2010, 25).

This Socio-Cultural Ecology or "Mobile Complex» is shaped by the individuals" usage of media and e.g. their everyday media literacy (agency). Socio-cultural structures play an important role in this ecology as media usage is also driven by the different aesthetic preferences of the socio-cultural milieux or social segments that structure modern societies. Technological structures mark current potentials for devices, networks and software. Cultural practices as the third cornerstone are sedimented routines which are part of a certain culture (e.g. the cultural assumption of how learning works in schools, or how we usually would use mobile phones in public). Each of these cornerstones and the way how they interrelate are subjects of constant change and negotiation as described in the term «mediatization». The question of the opportunities for media education of at-risk learners is founded on the theory of media education (German: Medienbildung) and the culturaltheoretical model of the Socio-Cultural Ecology (Pachler, Bachmair, and Cook 2010). It is based on Anthony Giddens' Structuration Model (Giddens 1984) and on the theory of media literacy as a cultural practice by David Buckingham (Buckingham and Sefton-Green 2003).

In order to describe the complex relationship between individuals, media and society within a wider context of appropriation and learning, it makes sense to use an ecological approach. This contribution tries to trace back the origins of Sociocultural Ecology. The focus of this text is to look closely on individual definitions and concepts of ecology. One of the central questions for this literature review is 
what the authors understand by «ecologys, examining the centres of the discussion in order to clarify why it is useful to apply an ecological approach. As found in Rummler (2012) Socio-Cultural Ecology can indeed be applied to the use of mobile technology of at-risk learners. Among of the concrete questions in this research were: "What does the Socio-Cultural Ecology of lower class adolescents (at-risk learners) look like and how does it differ from upper class adolescents?» The question of the role of media and technology still remains: Is media or technology a resource which is available for use and integration into one's own lifeworld and does it form contexts together with our own behaviour and use?

\section{Traditional concepts of ecology - The world as it used to be and the media}

The common core of the concepts of ecology presented in this section is the relationship between living organisms and the physical world. The physical world in this section includes all living organisms like people, animals, and plants, but also weather, climate, geology and biology. This applies to Human and Social Ecology, Cultural Ecology and Media Ecology. Semiotic Ecology goes beyond this, and asks whether such a concept of dividing the physical world from subjects and individuals is still valid when looking at nature in a mediated way. All of these concepts of ecology will only be outlined briefly. As media ecology had greater influence it will be outlined in a separate section. Bronfenbrenner's Ecological Model of child development with its great importance for educational sciences will sum up this chapter.

\section{Ecology as the relationship between living organisms and the physical world}

- Human and Social Ecology (Human- und Sozialökologie)

Social ecology is concerned with the relationship between people and their natural and social environment. The goal of this interdisciplinary academic field is help to develop and reproduce a society and its natural basis of life. (Becker and Jahn 2000) This concept which is strongly situated in sociology varies from the concept of Human and Social Ecology developed in the USA. The term «new ecological paradigm» was intended to include natural sciences as the interface between sociology and natural science to describe society as also dependant on biological and physical determinants.

\section{- Cultural Ecology (Kulturökologie)}

The academic field of "Cultural Ecology» was developed in the 1950s and studies the general relationship between human beings and the environment. The concept of «environment» is closely related to physical nature as biology, geology or meteorology. The field also covers questions about how mankind or society interferes with nature or how cultures change natural environments. Among the 
main founders were Julian Steward, who presented a "Theory of Culture Change» (1955), Fredrik Barth who researched «Ecologic relationships of ethnic groups» (1956) and Andrew P. Vayda who developed «An ecological approach to cultural anthropology» (1969).

Using on Cultural Ecology the Norwegian philosopher Arne Næss proposed the concept of «Ecosophy» or «Deep Ecology» (1973). With this «philosophy of ecological harmony» Næss tried to present a concept that combines the natural sciences and the ethical or philosophical dimension of how people should live with the environment or nature. This Ecosophy informed the environmentalist or «Green Movement» to a large extent in the late 1970s and early 1980s and introduced the notion of a balance between culture and nature.

The two American brothers Howard T. and Eugene Odum developed a more general approach to ecology. According to Hall (1995) Odum developed the following six scientific areas in relation to ecology: Ecological modelling, Ecological engineering, Ecological economics, Estuary ecology, and Tropical ecosystems ecology. Especially Odum's (1994) systems ecology with reference to general system theory could be relevant to describe a new «Cultural Ecology».

- Semiotic Ecology

The concept of ecology related to environments or nature is also visible in «Semiotic Ecology». Alfred Lang defines Semiotic Ecology as «a general conceptuality and methodology joining generative semiotic with the notion of ecology that living entities and their environment constitute each other in an open evolutive process» (Lang 1998). He describes Semiotic Ecology as a conceptual, systematic method for analysis of spaces as environments. Semiotic Ecology is used to understand ecological systems, in particular person-culture-systems (Lang 1997). A very similar approach was used by Ben Bachmair and Gunther Kress (1996; 1997), by Bovill \& Livingstone (2001) and by Heinz Moser, Christa Hanetseder and Thomas Hermann (2006) to analyse and describe children's rooms as a way of understanding the relation between children and media.

With reference to the Odum brothers Kalevi Kull (1998) points out on the necessity of extending the understanding of ecology because «the relationships between humans and nature are connected to deep cultural processes». He therefore stresses ecosemiotics or semiotic ecology in order to understand "the semiotic mechanisms which determine the place of nature in different cultures». Kull and Nöth (2000) explain that «Ecosemiotics (or ecological semiotics) is the study of sign processes in the interaction of humans with their natural environment. This semiotic field at the crossroads of nature and culture is most closely related to its neighboring fields of biosemiotics, zoosemiotics, and cultural semiotics, but semiosis in the relation between humans and nature is also of concern to aesthetics, the visual arts, literature, hermeneutics, and theology.» 
A different perspective on semiotic ecology is presented by Göran Sonesson (1999) and his attempt to describe the lifeworld as an ecology from the perspective of Peirce's semiotics. "Like Husserl's Lifeworld and Gibson's ecological physics, but unlike Greimas' natural world, semiotic ecology will suppose this particular level to be a privileged version of the world, «the world taken for granted», in Schütz's phrase, from the standpoint of which other worlds, such as those of the natural sciences, may be invented and observed. This world is characterised by a particular spatial and temporal structure, by types, and, by regularities» (Sonesson 1999, 9).

\section{Media Ecology}

The term Media Ecology was mainly shaped by Marshall McLuhan and Neil Postman in the mid 1970s in the USA. Marshall McLuhan encouraged Neil Postman to set up a Master programme on «Media Ecology»1 at the Steinhardt School of Culture, Education, and Human Development, University of New York. The «Media Ecology Association» (www.media-ecology.org) follows in this tradition.

The ecological environment within this concept is constituted by communication, dominated or mediated by media and technology. The ecology itself is the communicative environment of individuals or society. According to Neil Postman the purpose of media ecology is to explain the influence of technology on communication as well as the influence of new media environments that potentially change the way people think or organise their lives. The assumption is that media in the sense of artificial technology influence people and society in a negative way making them less capable and dependant on technology. (McLuhan 1964; Postman 1985)

McLuhan and Postman's concept of media ecology is considered not to be an empirical scientific approach but rather a philosophical one. It is not clear, furthermore, exactly how an ecology is constituted in this context in relation to the individual. Communication in the sense of a rather primal state is seen as the ecosystem which is spoiled by technology. The concept was thus not taken into account in central Europe.

One could even argue that the concept of mediatization (see above) opposes media and communication to culture and society, and that it thus stands in the tradition of Media Ecology. The authors further argue that research needs to study developments associated with media within mediatized worlds like family or school (Hepp and Krotz 2012, 13).

1 http://steinhardt.nyu.edu/dcc/masters/Media_Ecology.php [Nov 20th 2007]. 


\section{Ecological Model of child development}

Urie Bronfenbrenner is one of the most important developmental psychologists of the last decades and published his «Ecology of Human Development» (1979) impacting the social sciences, behavioural theories and pedagogy. His theory of social ecology from the 1980s was also the basis of a method set forth in Dieter Baacke's Media and Social Ecology Model in a German perspective. Bronfenbrenner's «eco-system» can be understood as the entire material and social environment. His concern was particularly the systematic interconnections of the family, the home, the school, the community and society in which people grow up. The individual is at the center of this model which forms more or less concentric circles around him or her, with the different types of eco-systems, which are related to Alfred Schütz's lifeworlds (dimensions of everyday life) are arranged in dependence on the intensity of the interaction of people in them, and the period of development:

- Microsystems cover the relationships to other people or groups,

- Mesosystems are the sum of the relationships (microsystems) of a child and the relationships between these microsystems,

- Exosystem is a system of relationships that the child does not belong to directly, so that they do not have a direct influence on him or her.

- Chronosystemes cover the temporal dimensions in the development of a child,

- The macrosystem covers all of the relationships in society including values, conventions, regulations etc.

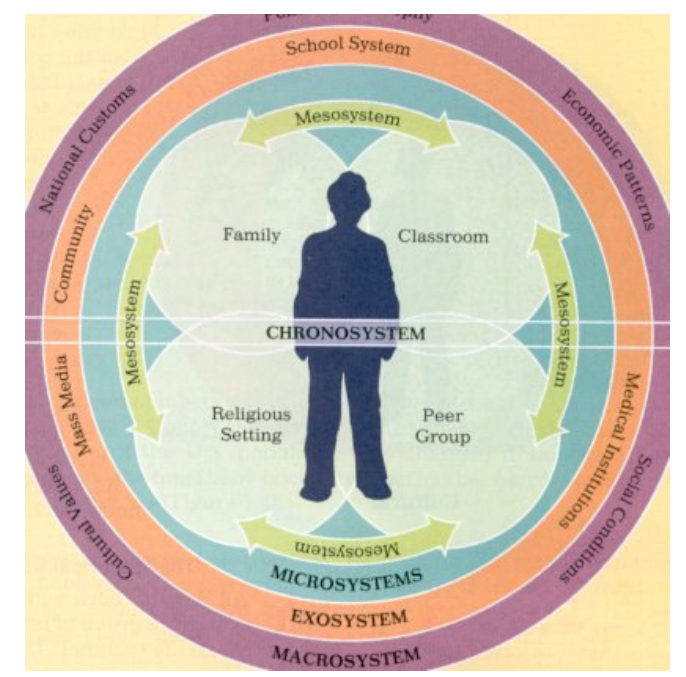

Fig. 2: Ecological Model of Child Development by Bronfenbrenner (Oconto Falls School District Community 2004, 4). 
Newer models of ecologies - Learners within their physical, structural world More recent approaches understand the physical world as including all living organisms, especially humans, as well as family, peers, teachers, third parties, etc. The structural world here refers to the structure of society, of the school system, of the school institution or of information mediated through technological resources. Considering the classroom as an ecological system is not uncommon and is based on the assumption that the effectiveness of the teacher is to be understood only within the context of community, family, school, and classroom. Additionally, the inschool performance of the students can only be explained within the ecosystem of the school. In particular the keywords school culture, school climate and classroom culture point out to this notion. Two of the most important representatives of this position are Chet A. Bowers and David J. Flinders (1990). Doll et al. (2004) argue in this spirit for a healthy class environment to support at-risk learners. Their handson book focuses on supporting the mental health and the school performance of students who lack social and emotional support. As part of the early research on mobile phone use of young people Grinter and Palen (2002) spoke about a domestic ecology with regard to the patterns of how the use of instant messaging is integrated.

The focus on individual systems, either within dominant ecologies or in single, related and adjacent ecologies, ultimately corresponds to Bronfenbrenner and his ecology model, which organized the subsystems according to their tasks and characteristics around the individual.

\section{Information and learning ecology}

A different and perhaps more useful approach to ecology is proposed by Nardi \& O'Day (1999) as an «information ecology». They define an «information ecology to be a system of people, practices, values, and technologies in a particular local environment. In information ecologies, the spotlight is not on technology, but on human activities that are served by technology» (Nardi and O'Day 1999, 49).

Nicola Beddall-Hill explains the importance of this theory's

focus upon the human practices that are served by technology, proposing that microenvironments such as hospitals and libraries are information ecologies. In these settings people, technology and other artefacts come together in congenial relationships that are driven by the values that are present in that ecology. [...] Ecologies are used in a metaphorical sense to represent complex diversity where many relationships are taking place and most importantly they are continually evolving. They are a system which fit together. (Beddall-Hill 2012, 2) 
In this context John Seely Brown (2002) assumes that the internet provides great amounts of writing, information and interest groups that act as resources for learning. He then introduces the term «learning ecology» and defines that:

An ecology is basically an open, complex, adaptive system comprising elements that are dynamic and interdependent. [...] Now recall our emphasis that informal learning often involves the joint construction of understanding around a focal point of interest, and one begins to sense how these crosslinked interest groups, both real and virtual, form a rich ecology for learning.

Frielick (2004) formulates this approach specifically for classroom teaching by stating: "the key idea is that teaching/ learning is an ecosystemic process of transforming information into knowledge, in which teacher-subject-student relationships are embedded or situated in a context where complex interacting influences shape the quality of learning outcomes. This perspective goes beyond constructivism, into a new ecology of cognition and learning». He further points out that to «understand this new ecology of learning, we have to (de-learn. De-learning is a dual, synchronous process of deconstruction and enacting new understandings» (Frielick 2004, 328).

\section{Ecology of Resources}

The introduction of information and learning ecologies put the learner and the individual's learning clearly into focus. The learner is surrounded by and interrelated in practices with artefacts as well as information. Rosemary Luckin et al. $(2005 ; 2008)$ substantiated this standpoint by formulating a learner-centric ecology of resources, which is «a set of inter-related resource elements, the interactions between which provide a particular context». The learner centric ecology of resources or the «learning context» has a static dimension through which the resources can be identified and categorized, and a dynamic dimension that describes the organizing activities that activate the resources.

Central foci are:

- The use of technology as a means to provide continuity across informal learning outside school and formal learning in classrooms by appropriate contextualization of activities across school and home contexts.

- The inter-relatedness of the resource elements, providing certain responsive contexts that need to enabled by organizing activities.

- Different settings and contexts that require learners to adopt certain strategies to act within these contexts and vice versa. Students create different contexts by using technology, information and resources in different settings. 


\section{Recent concepts of Ecology}

More recently Digital Media Ecology has been used to describe the «relationships between new forms of education, mediated communication and cultural production as constitutive of a unitary media ecology» (Hug, Lindner, and Bruck 2006). More generally Michael Gieseke has described a new cultural and media ecology in his account of the transformation processes of media and written cultures (2002). In the perspective of German media education Media \& Social Ecology (Medienökologie), has provided new means to understand the complex relationship between young people and their use of media in everyday life (Lange and Lüscher 2000; Ganguin and Sander 2006).

\section{Media \& Social Ecology (Medienökologie)}

Andreas Lange and Kurt Lüscher (2000) use human and social ecology as the framework for their interpretation of the relation between television and children. Key concepts for their media ecological perspective are:

- The term «ecology» is used in two different ways: 1) Generally as description for lifeworlds that are meaningful for the development of people as biological, physical and social beings, and 2) for analysis of the relationships that develop between organisms and their lifeworlds.

- The term «human ecology» describes the lifeworlds that are relevant for the development of individuals, communities and societies on the one hand and the related scientific analysis on the other hand.

- Lange and Lüscher refer to social ecology in order to explain the relationships of individual people to wider social networks and systems. They include material and symbolic resources as well as restrictions. The concept and terms of social ecology used here are actually the same as Bronfenbrenner's, although this is not made explicit.

- Lange and Lüscher point out the importance of communication as mediator between individuals and their lifeworld. Insights gained from communication allow the creation of communication and media.

- The authors see media as ways of organizing human communication by means of technology and devices.

- Media ecology is thus seen as the part of media that is within the lifeworld as well as the analysis of consequences that the media have on the development of individuals and societies.

- The authors use "ecology of communication» to describe the collectivity of communicative processes.

- In parallel to social and media ecology the authors use «knowledge ecology» in order to describe individual and collective knowledge which people use to qualify the material and symbolic resources within social and media ecology. 
In this scheme media are seen as an external influencing factor on children and their lifeworld. Lange and Lüscher's Media Ecology is not able to see the relation between people and media as an interwoven and balanced system.

\section{Dieter Baacke's Media Ecology}

The most recent text on media ecology by Sonja Ganguin and Uwe Sander (2006) reviews the concept of ecology by Dieter Baacke from the 1980s and 1990s. Dieter Baacke, who died in 1999, was one of the key players in media education in Germany. .

In their text Ganguin \& Sander rely on Baacke, who in turn uses Brofenbrenner's social ecology (see section 2.3) to further explain children's and adolescent's social ecology. Baacke summarized Bronfenbrenner's categories of the macrosystem (micro-, meso-, exo-) in a concentric scheme consisting of an ecologic centre, a proximal ecological space, an ecological «cutout» and an ecological periphery. Relating the issue of media to the social ecological zones led to the approach of media ecology. The authors describe that within this scheme, as children grow up they get more and more in touch with the outer circles.

The ecological centre is closest to the individuals where children make their first experiences with media. This happens mostly in the home or family context. In this zone the child listens to the radio and to music, views television, eventually acquiring other media like a private television set and/or a personal mobile phone.

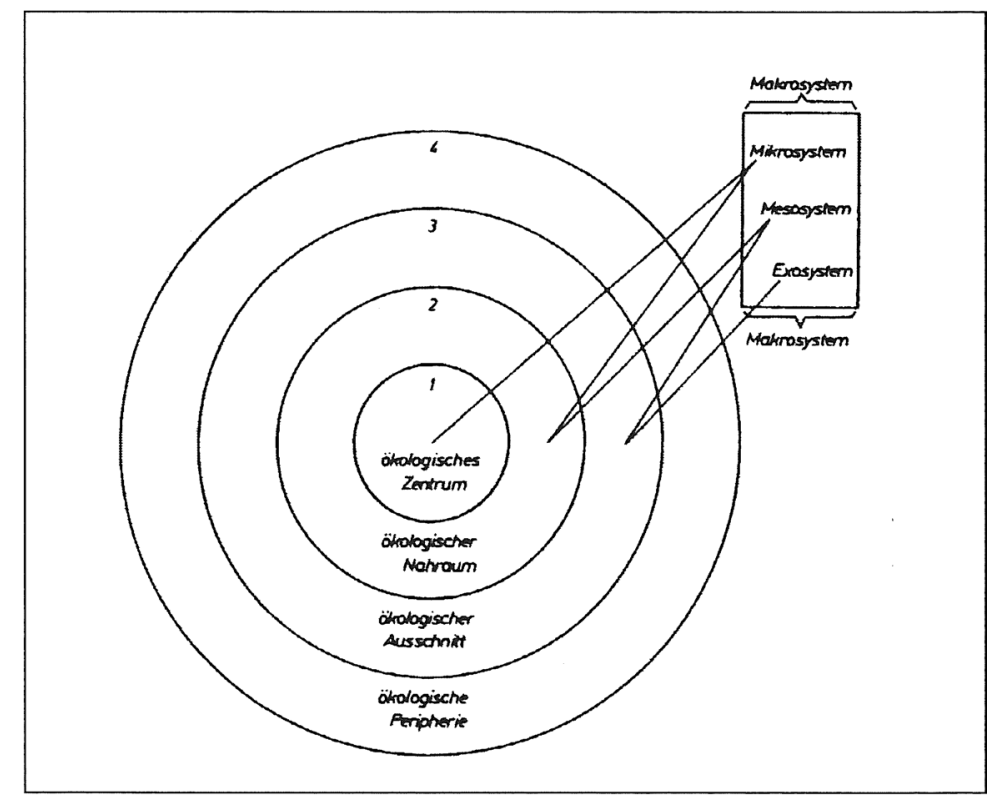

Fig. 3: Schematic order of the four ecological zones integrated in Bronfenbrenner's categories (Baacke 1983, 59; as found in: Ganguin and Sander 2006, 134). 
In the next concentric zone, the ecological proximal space, peer activities take place. In a spatial sense this means leaving the family and stepping outside on the street or going to the neighbours to meet friends. The media use in this context might be listening to mp3 songs stored on the mobile phone or talking about media experiences. The authors point out that such leisure-time activities depend on the quality and availability of this space, the persons and parental activities, all which are often more conspicuous (sometimes by their absence) in less affluent neighborhoods. The «ecological cutout» zone designates places where functional tasks and relationships are defined. These are for example the school or the job. This zone is shaped by institutions and associated experiences, affordances and tasks. In relation to media use, Baacke distinguishes between specific media environments like cinemas, libraries, discotheques or internet cafés, and nonspecific ones. These former are dedicated to a certain pattern of media use. The non-specific media environments in the ecological «cutout» are places that are not specifically dedicated to media use, but where media is still available like music listening or playing in a youth club or in a café.

The fourth zone with the greatest distance to the centre is the ecological periphery; it is characterised by casual contacts or occurrences like holiday trips. Media use also takes place in this zone and is highly relevant for orientation within other, outer socio ecological zones.

According to Dieter Baacke the variety and quality of the ecological zones is most important. The more enriched and versatile this variety and quality, the more open and widely-experienced children become. The more liberty of action, opportunities for communication and action that children are offered in each of the zones, the stronger their development. This becomes obvious with the example of impoverished or «marginalized» families who might not be able to offer children these opportunities or who are socially excluded from certain activities or who do not have access to certain media technology or networks.

The authors Ganguin and Sander state that the ecological model with its zones is just analytical and not empirical. The zones are not clearly and strictly separate form each other and overlap especially considering media use. The socio ecological zones by Bronfenbrenner and Baacke imply two dimensions: The dimension of child development and growth and the dimension of space. It seems unclear how these two dimensions are relevant for media use, especially for the use of mobile phones or the internet.

\section{Consequences and tasks for education and mobile learning in schools}

The aims of this review are to explore different concepts of "ecology» as it forms the basic metaphor for the Socio-cultural Ecology of mobile learning or «mobile complex». A further aim was to explore different meanings of ecology in the 
context of learning and media use. The question with ecology often is: «What is in the centre and in which context does it take this position?» Among the results of this exploration are:

- In the various concepts of ecology there exists a certain differentiation between the system and nature. Although those are often subtle differentiations, some concepts have certain notions about natural states of communication and lifeworlds, or natural systems that used to work without technology.

- It needs to be stated that the notion of nature - in the sense of an unspoiled environment - should be transformed into a notion of the nature of an «ecology».

- Consequently, it might be useful to consider that it is an ecologies nature to be stable, but that ecologies are systems that are about to change. Ecologies are - if we want to speak of anything natural - subject to change by nature (Goddard and Parikka 2011).

- Ecologies are technical, social, cultural or spatial systems whose components cannot be deconstructed or be taken apart. Their elements are interdependent and closely inter-related.

- An ecological approach in education needs to put individuals in the centre. The relationship between the individual in the centre and the outside worlds can be characterised through reference to equilibrium or balance, correspondence and/or reciprocity.

- More generally, ecology needs to be seen as «dynamic interrelation[s] of processes and objects, beings and things, patterns and matter» (Fuller 2005, 2) «in a culture where the relation between materiality and information has been redefined» (Goddard and Parikka 2011).

Cultural practices of school learning and of media acquisition take place in different worlds or in different ecological zones / spheres. The cultural definitions of media in the context of entertainment and formal learning in the context of school have led to contradictory forms of learning (Bachmair 2008). In-school and everyday media use can be assigned to different zones of social ecology, with school taking place in the ecological cutout where other functional institutions are located and where specific tasks are to be solved. The non-specific media use takes place, according to Baacke, in the ecological centre and in the ecological proximal space. As agency in the context of everyday life joins with the structures of learning from school it is therefore necessary to identify structural relations between school and everyday life (Bachmair 2008) and to break the strict barriers between the socioecological zones in relation to school and media.

In other words, learning in school and media use in leisure time can be considered as different cultural situations each with its own set of cultural practices of learning. 
The question for research and teaching design is then: How do children develop agency in certain cultural situations and what affordances are implied in certain cultural situations? Learning in school means obtaining competencies and skills at a common level, whereas media use in the sense of using cultural resources means to individually acquire a degree of agency in the world of consumption and entertainment outside school. This has certain implications and raises questions for the concept of «cultural resources». One question would be: «Can learning in school also be described as the acquisition of agency in the context of cultural resources?» Or: «How do cultural resources from outside school differ from cultural situations inside school?»

In both economic and instructional design terms, the word "ecology» implies a high degree of responsibility (Zacharias 1999; Bachmair 2008). This includes a commitment to protect learners from economic exploitation (Pachler, Bachmair, and Cook 2013, 35f) and respecting sustainability in the use of resources, providing open spaces for play and learning, and open choices.

Creating «reciprocity of mobile devices, everyday life and formal learning [means to acknowledge, K.R.] the naive expertise (of media use) in everyday life that students bring into educational situations. Assimilation means to recognize such naive expertise. Reciprocity as a basis for the assimilation of cultural mobile resources by formal eduction can be realized practically through a mobile investigation of schools as learning environments» (Pachler, Bachmair, and Cook 2013, 37).

It remains for teaching design and media education to connect and balance experiences with the phenomena and structures in the real world. In addition rich, versatile and open media environments and opportunities should be provided for children to experience for the sake of their development and critical reflection in all zones, contexts and situations.

\section{Literature}

Baacke, Dieter. 1983. Die 13- bis 18jährigen: Einführung in Probleme des Jugendalters. 3. Aufl. Weinheim und Basel: Beltz Verlag.

Bachmair, Ben. 1997. «Ein Kinderzimmer als Text». Medien Impulse, Beiträge zur Medienpädagogik 19 (2): 59-62. Accessed 10.7.2014. https://kobra.bibliothek. uni-kassel.de/bitstream/urn:nbn:de:hebis:34-2009061028177/1/BachmairKinderzimmerAlsText.pdf.

Bachmair, Ben. 2008. «Kulturell situiertes Handeln und Lernen: der Gedanke der Kulturökologie». Medien Journal - Zeitschrift für Kommunikationskultur, hrsg. v. Margit Böck, 1 (32): 19-30.

Bachmair, Ben und Gunther Kress, Hrsg. 1996. Höllen-Inszenierung (Wrestling): Beiträge zur pädagogischen Genre-Forschung. Opladen: Leske + Budrich. Accessed 10.7.2014. https://kobra.bibliothek.uni-kassel.de/bitstream/urn:nbn :de:hebis:34-2007090719187/1/BachmairWrestling.pdf. 
Barth, Fredrik. 1956. «Ecologic relationships of ethnic groups in Swat.» North Pakistan. American Anthropologist 58 (6): 1079-108.

Becker, Egon und Thomas Jahn. 2000. "Sozial-ökologische Transformationen: Theoretische und methodische Probleme transdisziplinärer Nachhaltigkeitsforschung.» In Nachhaltigkeit und Transdisziplinarität, hrsg. v. Karl-Werner Brand, 68-84. Berlin: Analytica.

Beddall-Hill, Nicola. 2012. «Information Ecologies - A useful approach for observing «mobile learning in the wild??» In Mobile and Contextual Learning 2012. Proceedings of the 11th International Conference on Mobile and Contextual Learning 2012, ed. Marcus Specht, Mike Sharples and Jari Multisilta, 955: 34 37. CEUR Workshop Proceedings. Helsinki, Finland: CEUR-WS.org. Accessed 10.7.2014. http://ceur-ws.org/Vol-955/papers/paper_51.pdf.

Bovill, Moira and Sonia M. Livingstone. 2001. «Bedroom culture and the privatization of media use.» In Children and their changing media environment: A European comparative study, ed. Sonja M Livingstone and Moira Bovill,179-200. London: Lawrence Erlbaum.

Bowers, Chet A. and David J. Flinders. 1990. Responsive teaching: an ecological approach to classroom patterns of language, culture, and thought. Vol. 4. Advances in Contemporary Educational Thought Series, Early Childhood Education Series. Teachers College Press.

Bronfenbrenner, Urie. 1979. The ecology of human development: experiments by nature and design. Harvard: Harvard University Press.

Brown, John Seely. 2002. "Growing up Digital. How the Web Changes Work, Education, and the Ways People Learn.» Journal of the United States Distance Learning Association 16 (2) (February). http://www.usdla.org/html/journal/ FEB02_Issue/article01.html.

Buckingham, David and Julian Sefton-Green. 2003. "Gotta catch 'em all: Structure, Agency and Pedagogy in Children's Media Culture.» Media, Culture \& Society 25 (3): 379-399. doi:10.1177/0163443703025003005.

Doll, Beth, Steven Zucker, and Katherine Brehm. 2004. Resilient classrooms: creating healthy environments for learning. The Guilford Practical Intervention in the Schools Series. Guilford Press.

Frielick, Stanley. 2004. «Beyond constructivism: an ecological approach to e-learning.»In Beyond the comfort zone: Proceedings of the 21st ASCILITE Conference, ed. Roger Atkinson, Clare McBeth, Diana Jonas-Dwyer and Rob Phillips, 328-332. Perth. http://www.ascilite.org.au/conferences/perth04/procs/ frielick.html.

Fuller, Matthew. 2005. Media Ecologies. Materialist Energies in Art and Technoculture. Cambridge, Massachusetts; London, England: The MIT Press. 
Ganguin, Sonja und Uwe Sander. 2006. «Medienökologie.» In Qualitative Medienforschung: Ein Handbuch, hrsg. v. Lothar Mikos u. Claudia Wegener, 130-140. Konstanz: UVK Verlagsgesellschaft.

Giddens, Anthony. 1984. The constitution of society: outline of the theory of structuration. Cambridge: Polity Press.

Giesecke, Michael. 2002. Von den Mythen der Buchkultur zu den Visionen der Informationsgesellschaft. Frankfurt a. Main: Suhrkamp.

Goddard, Michael; Parikka, Jussi. 2011. «Editorial: Unnatural Ecologies.» The Fibreculture Journal 17. http://seventeen.fibreculturejournal.org/.

Grinter, Rebecca E. and Leysia Palen. 2002. «Instant Messaging in Teen Life». In Computer Supported Cooperative Work. Proceedings of the 2002 ACM conference on Computer supported cooperative work, 21-30. New York: ACM Press. doi:10.1145/587078.587082. http://doi.acm.org/10.1145/587078.587082.

Hall, Charles AS, ed. 1995. Maximum power: the ideas and applications of H.T. Odum. University of Michigan: University Press of Colorado.

Hepp, Andreas und Friedrich Krotz. 2012. «Mediatisierte Welten: Forschungsfelder und Beschreibungsansätze - Zur Einleitung.» In Mediatisierte Welten, hrsg. v. Friedrich Krotz u. Andreas Hepp, 7-23. VS Verlag für Sozialwissenschaften. http://www.springerlink.com/content/ht725g1j4k4333383/abstract/.

Hug, Theo, Martin Lindner, and Peter A. Bruck, ed. 2006. Micromedia \& e-Learning 2.0: Gaining the Big Picture. Proceedings of Microlearning Conference 2006. Conference Series. Innsbruck: Innsbruck University Press.

Kull, Kalevi. 1998. "Semiotic ecology: different natures in the semiosphere». Sign Systems Studies 26: 344-371. http://www.zbi.ee/ kalevi/ecosem.htm.

Kull, Kalevi, and Winfried Nöth. 2000. «Discovering ecosemiotics.» Sign Systems Studies 1: 421-424.

Lang, Alfred. 1997. "Non-Cartesian artifacts in dwelling activities: Steps towards a semiotic ecology.» In Mind, culture, and activity: seminal papers from the Laboratory of Comparative Human Cognition, ed. Michael Cole, Yrjö Engeström, and Olga A. Vasquez, 185-202. Cambridge: Cambridge University Press.

Lang, Alfred. 1998. "Papers (in English) on Generative Semiotic and Semiotic Ecology.» SemEcoPro. http://lbau.co/spec/0871semecogensem.htm.

Lange, Andreas und Kurt Lüscher. 2000. «Kinder und ihre Medienökologie in spostmodernen` Zeiten: Soziologische Anmerkungen zur Medienpädagogik.» merz - medien + erziehung 1: 41-50.

Luckin, Rosemary. 2008. "The learner centric ecology of resources: a framework for using technology to scaffold learning.» Computers \& Education 50 (2): 449462. doi:10.1016/j.compedu.2007.09.018. 
Luckin, Rosemary, Benedict du Boulay, Hilary Smith, Joshua Underwood, Geraldine Fitzpatrick, Joseph Holmberg, Lucinda Kerawalla, Hilary Tunley, Diane Brewster, and Darren Pearce. 2005. "Using Mobile Technology to Create Flexible Learning Contexts». Journal of Interactive Media in Education 22 (December). http://jime.open.ac.uk/jime/article/download/2005-22/300/116-1159-1-PB.pdf.

McLuhan, Marshall. 1964. Understanding media: the extensions of man. New York: McGraw-Hill.

Moser, Heinz, Christa Hanetseder und Thomas Hermann. 2006. «Embodied Spaces: Medien im alltagsästhetischen Arrangement.» In Mediennutzung, Identität und Identifikationen: Die Sozialisationsrelevanz der Medien im Selbstfindungsprozess von Jugendlichen, hrsg. v. Lothar Mikos, Dagmar Hoffmann u. Rainer Winter, 247-262. Weinheim und München: Juventa Verlag.

Næss, Arne. 1973. "The Shallow and the Deep, Long-Range Ecology Movement.» Inquiry (16): 95-100.

Nardi, Bonnie A., and Vicki L. O'Day. 1999. Information ecologies: using technology with heart. Massachusetts Institute of Technology.

Oconto Falls School District Community. 2004. "Appendix B. Bronfenbrenner's Ecological Model of Child Development.» University of Wisconsin. http:// oconto.uwex.edu/files/2011/02/AppendixB-BronfenbrennersEcologicalModel ofChildDevelopment.pdf.

Odum, Howard T. 1994. Ecological and general systems: an introduction to systems ecology. University of California: University Press of Colorado.

Pachler, Norbert, Ben Bachmair, and John Cook. 2010. Mobile Learning: Structures, Agency, Practices. New York: Springer. http://dx.doi.org/10.1007/978-1 -4419-0585-7.

Pachler, Norbert, Ben Bachmair, and John Cook. 2013. "A Sociocultural Ecological Frame for Mobile Learning.» In Handbook of Mobile Learning, ed. Zane L. Berge and Lin Y. Muilenburg, 35-46. New York: Routledge.

Postman, Neil. 1985. Amusing ourselves to death: public discourse in the age of show business. New York: Penguin Books.

Rummler, Klaus. 2012. Medienbildungschancen von Risikolernern: Eine Analyse der Nutzung mobiler und vernetzter Technologien durch männliche jugendliche Risikolerner und die in den Nutzungsmustern angelegten Chancen für Medienbildung. Kassel: Universität Kassel. http://nbn-resolving.de/urn:nbn:de :hebis:34-2012120642264.

Sonesson, Göran. 1999. "Iconicity in the ecology of semiosis.» In Iconicity: a fundamental problem in semiotics, ed. Troels Degn Johannsson, Martin Skov and Berit Brogaard, 1-16 [59-80]. Århus N, Denmark: NSU Press. http://www.academia .edu/491683/Approaches_to_the_Lifeworld_core_of_visual_rhetoric. 
Steward, Julian Haynes 1955. Theory of culture change: the methodology of multilinear evolution. Urbana: University of Illinois Press.

Vayda, Andrew P. 1969. "An ecological approach to cultural anthropology.» Bucknell Review 17: 112-119.

Zacharias, Wolfgang. 1999. "Auf der Suche nach einer pädagogisch akzentuierten 〈Medienökologie» zwischen «senses \& cyber〉.»In Interaktiv - Medienökologie zwischen Sinnenreich und Cyberspace: Neue multimediale Spiel- und Lernumwelten für Kinder und Jugendliche, hrsg. v. Wolfgang Zacharias, 50-81. München: kopead. 